\title{
Cultural codes as an instrument of lingua-cultural studies of Persian omens and superstitions
}

\author{
S. Sopilniak \\ Institute of Philology of Taras Shevchenko National University of Kyiv \\ Corresponding author. E-mail: sveta_sopilnyak@ukr.net
}

Paper received 03.12.18; Revised 07.12.18; Accepted for publication 08.12.18.

\section{https://doi.org/10.31174/SEND-HS2018-184VI30-08}

\begin{abstract}
The article examines the concept of "cultural code" as a mean of investigation of Persian omens and superstitions in the context of cultural linguistics. Since omens and superstitions are characterized by a complex of lingua-cultural and lingua-cognitive features, the research of these units can open the way to the mental sphere and the mode of thinking of the representatives of a certain linguistic culture. The author offers a classification of Persian omens and superstitions according to the cultural codes and presents a statistical analysis of lingua-cultural units in the light of cultural codes studies.
\end{abstract}

Keywords: cultural code, Persian language, omen, superstition, cultural linguistics.

Introduction. It is known that different languages reflect reality and national characteristics of every nation in different ways, and culture is an essential part of this reality. Language is a product of culture, its component and its tool. Looking for an acceptable tool for the study of Persian omens and superstitions as unique linguacultural units of language, I turned to the study of cultural codes, as far as the linguistic picture of the world of any nation is specified by nationally determined cultural codes.

A brief review of publications on the subject. The concept of code came in cultural linguistics from semiotics. In this science "code" is defined as a system that contains the structure of signs and the rules of their functioning. The structure, in turn, consists of signs themselves and the links between them [3]. M.I. Tolstoy and S.M. Tolstaya were among the first scholars who started to use the term "cultural code" when analyzing Slavic rituals [6]. The concept of "cultural code" in the light of cultural linguistics was developed by scholars such as V.A. Maslova, V.M. Teliya, V.V. Krasnyh, H.V. Tokarev, M.L. Kovshova and others.

Objective. The present paper aims to find out if cultural codes are an acceptable instrument for investigation and systematization of Persian omens and superstitions.

The research material and methods. The author used 202 Persian omens and superstitions as a material for the research. A number of methods, in particular, method of analysis, synthesis, classification, contrast method, as well as information gathering and searching methods were used.

Results and Discussion. The "enclosed" cultural information in the codes takes an important place in the matter of cultural codes. O.L. Berezovich claims that this is "information about the world, which is fixed in a symbolic form, that is, it has a linguistic and cultural marking. The content of this information is determined not so much by the objective "photographing" of the reality, but by the subjective-naive world perception of the bearer of the tradition which has an ethnic, social and cultural basis" $[1$, c. 9].

V.V. Krasnyh believes that "cultural code is a "net" that culture "casts on the world, categorizes, structures and evaluates it". Cultural codes are related to the most ancient archetype humans' beliefs. Properly speaking, cultural codes "encode" these beliefs. Cultural codes as a phenomenon are universal by their nature and appropriate to a man as homo sapiens. However, their manifestations, the proportion of each of them in a certain culture, as well as the metaphors in which they appear, are always nationally determined and conditioned by a particular culture" $[2$, c. 5$]$.

V.M. Teliya defines the cultural code as "taxonomic substrate of cultural texts". "This substrate is a set of cultured beliefs about the picture of the world of a certain society, which includes natural objects, artifacts, phenomena, actions and events, mentifacts and their spatialtemporal or qualitative-quantitative dimensions inherent in these entities. For example, material, action, code of ritual forms of behavior, cosmological, zoological, myth code, etc." [4, c. 153].

Analyzing universal basic codes of culture, researchers distinguish the following main varieties: 1) somatic; 2) spatial; 3) time; 4) material; 5) biomorphic; 6) spiritual [5, c. 29-32].

However, cultural codes can be grouped, categorized and classified differently. For example, within the biomorphic code, one can distinguish zoomorphic and floral codes, and within the latter one arboretum and floristic codes can be found. V.M. Teliya and the group of authors who compiled "The Great Phraseological Dictionary of the Russian Language" defined fifteen cultural codes and noted that their list is not exhaustive [5, c. 29-32].

Thus, in the scientific literature there is no single, exhaustive classification. Different researchers distinguish various sets of cultural codes. However, the idea of using this research tool in order to classify omens and superstitions as units of the Persian picture of the world seems to be as quite acceptable and fruitful.

Having analyzed Persian omens and superstitions (in the amount of 202 units), we may identify 10 cultural codes and systematize all the collected material according to these codes. The classification was made according to the part of the linguistic unit, on the basis of which, in fact, the forecast is made. It was found that some superstitions can be attributed to two different cultural codes. For example, Persian superstition "If someone gets a pigeon or sparrow from a pit at night, his life will be shortened" "اكر كسى شب از توى جاه كبوتر و كنجشى بكَيرد، عمرش كوتاه ) may be classified into two codes: zoomorphic and time-spatial codes since it focuses on the time of day, 
namely, on night, and on representatives of the animal world, namely, on birds: a dove or a sparrow.

Thus, the largest first group consists of superstitions, which may be attributed to the zoomorphic cultural code (58 superstitions). For instance, "Gazelle and partridge have an evil eye, so you should not keep them in the house" ( آهو و كبك جشمشان شور است و نبايد آنها را در منزل " نحه داشت ( If raven cows on the hunter's way, it is believed, that hunter will get a lot of prey. But if the hunter

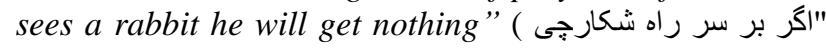

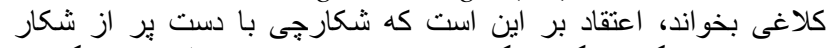

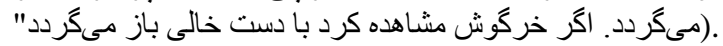

Superstitions of the somatic code make the second group (35 superstitions). For example, "To bite the tongue means that somebody is gossiping about you” "هر") (كس زبان خود را كاز بكيرد در آن ساعت غييت او را مىكنند" "Do not throw the cut nails on the ground, otherwise, poverty will come” ( ناخنهاى كوتاه شدهات را روى زمين نريز، فقر

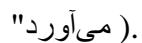

Superstitions of the anthropic (human) code make the third group (29 superstitions). For example, "To

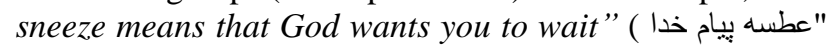
"براى صبر كردن است ); "If a wedding celebration or a feast on the occasion of somebody's return from Hajj are going to take place in your house, then luck will come to your

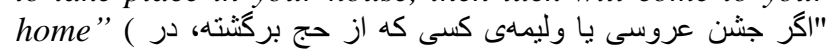

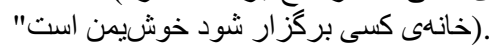

The fourth group consists of superstitions of the subject-artifact code (23 superstitions). For example, "At-

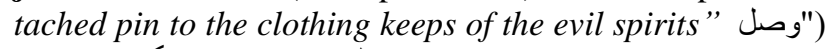
كردن سنجاق به لباس مانع جن زدگى مىشود" :In order to protect the child from the evil eye, some things put on her neck"” (به كُردن كودك اثشيايى بر ای دور ماندن از جشم زخم مى آويزند ").

The fifth group is made by superstitions of the gastronomic code (22 superstitions). For instance, " If women preparing the food eat the top of a dish from a pan, then

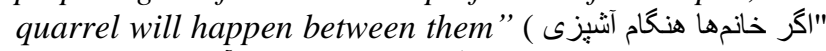
"It is believed that if a slice of sugar accidentally fell into a glass of tea, then

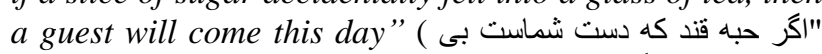

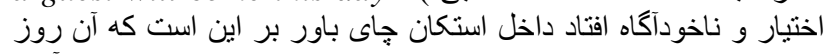

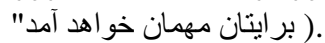

The sixth group consists of superstitions of the timespatial code (20 superstitions). For example, "If a pregnant woman walks alone at night under a tree or in abandoned places, the shadow of genies will fall upon her and

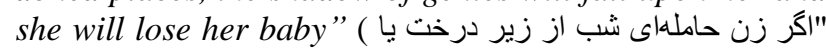

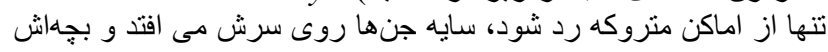
" سقط مىشود : ); "It is believed that Saturday is an unlucky day, so you should not lend milk, mast ${ }^{1}$, cheese or some-

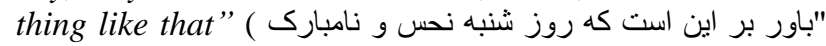

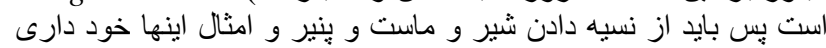

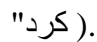

Superstitions of the natural code make the seventh group (12 superstitions). For example, "If it rains on a

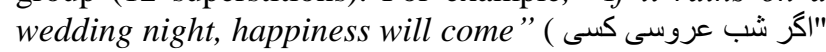
(باران ببارد، خوشبخ مى شود"); “The superstitions say that pointing a finger at the stars is the same as pointing a finger at a stranger on the street. It can bring a failure or

\footnotetext{
${ }^{1}$ Mast - a traditional Iranian sour-milk product which is similar to unsweetened yogurt.
}

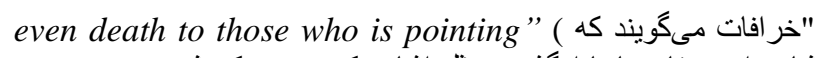

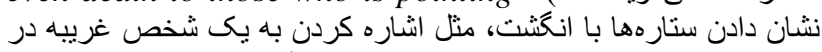

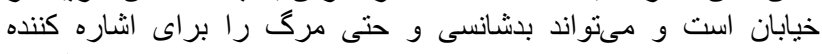

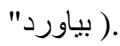

The eighth group consists of omens and superstitions of the theomorphic code (9 superstitions). For example, "If a pregnant woman reads Surah Muhammad, she will

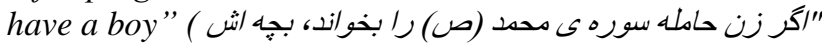
(بسر مسى شود"); "It is believed that if somebody sprinkles the leftovers from Saint Sakinah's tablecloths on the head of

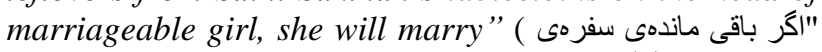
حضرت رقيه (س) را بر سر دختر دم دم بخت بريزند، بر اين باورند كه بخت

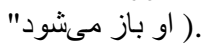

The ninth group consists of omens and superstitions of the floral code ( 7 superstitions). For instance, "The acorn put down behind the window will help to ward off

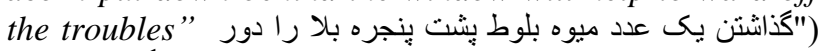
(نحشه مىدارد"; "Do not spread garlic skin in the air, be-

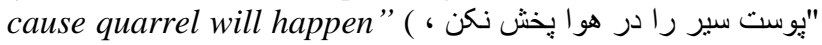
"دعوا مىشود ).

Superstitions of the quantitative code make the last tenth group (5 superstitions). For example, "If a pregnant woman simultaneously gives birth to two or three girls, then goodness, grace and development will come to the

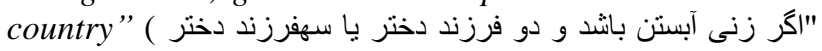

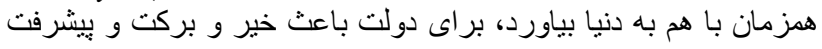

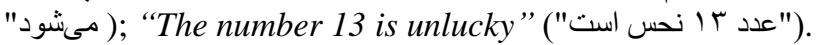

Therefore, according to the results of our classification of Persian omens and superstitions, the zoomorphic code (29\%) made the largest group of superstitions. Moreover Iranians usually focus on butterflies, birds, cats, chickens and chicken eggs in their superstitious beliefs. The second and third largest groups are made by superstitions of somatic $(17 \%)$ and anthropic codes (14\%). It is reasonable to combine somatic and anthropic codes, because they are related to various aspects of human activity and in fact with a human itself and parts of its body. In this case this kind of superstitions makes the biggest group (32\%). The fact is that micro-genres we have researched are rooted in ancient times when human started to discover the world from itself and its place in nature and only after that studied the environment. Much attention was paid to the observation of the behavior of animals, birds and insects; therefore, the zoomorphic code contains so many omens $(29 \%)$. The subject-artifact $(11 \%)$, gastronomic (11\%) and time-spatial $(10 \%)$ codes have approximately the same number of superstitions. The following cultural codes are natural (6\%), theomorphic (4\%) and floral $(3 \%)$. The smallest group consists of superstitions belonging to the quantitative code $(2 \%)$.

Conclusions. Having chosen cultural codes as an instrument for creation a classification of Persian omens and superstitions, the author discovered that researchers distinguish a different number of cultural codes the combinations of which can vary in different ethnic societies. In order to find out the Persian ethnicity in this respect, the author found it appropriate to classify Persian omens and superstitions according to the codes of culture. The collected Persian omens and superstitions were classified according to the ten cultural codes, such as: 1) zoomorphic; 2) somatic; 3) anthropic; 4) subject-artifact; 5) gastronomic; 6) time-spatial; 7) natural; 8) theomorphic; 9) floral; 10) quantitative. The zoomorphic code made the 
largest group of superstitions and the quantitative code made the smallest one. The classification made it possible to establish that, while creating omens and superstitions, Iranian people focus on the following objects and phenomena of the reality: various aspects of human life, human activities, physical condition, facial features, behavior of animals, birds and insects, natural phenomena, flora and celestial bodies. In addition, Iranians pay attention to household equipment, certain foodstuffs and often turn to religion.

\section{REFERENCES}

1. Berezovich E.L. Language and traditional culture: Ethnolinguistic studies / E.L. Berezovich. - M. : Indrik, 2007. $600 \mathrm{p}$.

2. Krasnyh V.V. Linguistics. Codes and standards of culture (invitation to talk) // Language, consciousness, communication: articles / V.V. Krasnyh. - M. : MAKS Press, 2001. - Is.19. - 164 p.

3. Semiotics // Encyclopedia Krugosvet. Universal popular science online encyclopedia [Electronic resource] - Acceptabe http://www.krugosvet.ru/enc/gumanitarnye_nauki/lingvistika/ SEMIOTIKA.html

4. Teliya V.N. Russian phraseology. Semantic, pragmatic and linguocultural aspects / V.N. Teliya. - M. : Shkola «Languages of Russian culture», 1996. - 288 p.

5. The Great Phraseological Dictionary of the Russian Language / [edit. by V.N. Teliya]. - M. : AST-PRESS KNIGA, 2006. $784 \mathrm{p}$.

6. Tolstoy N.I. Slavic ethnolinguistics: theory issues / N.I. Tolstoy, S.M. Tolstaya. - M. : Institute of Slavic Studies RAN, 2013. -240 p. 